\title{
Alterations of protein expression in conditions of copper-deprivation for Paracoccidioides lutzii in the presence of extracellular matrix components
}

\author{
Haroldo Cesar de Oliveira ${ }^{1}$, Julhiany de Fátima da Silva ${ }^{1}$, Marcelo Teruyuki Matsumoto ${ }^{1}$, Caroline Maria Marcos ${ }^{1}$, \\ Roberta Peres da Silva', Rosângela Aparecida Moraes da Silva', Mônica Teresa Veneziano Labate², \\ Carlos Alberto Labate ${ }^{2}$, Ana Marisa Fusco Almeida ${ }^{1}$ and Maria José Soares Mendes Giannini ${ }^{*}$
}

\begin{abstract}
Background: Paracoccidioides spp is a fungi genus and the agent of paracoccidioidomycosis. The strategies of infection used by these pathogens involve the expression of proteins related to adaptation to the host, particularly regarding the uptake of micronutrients. This study analyzed the adhesion of Paracoccidioides /utzii during conditions of copper (Cu) and iron (Fe) deprivation, while also evaluating the proteins expressed in conditions of Cu depletion in the presence of four extracellular matrix (ECM) components (laminin, fibronectin and types I and IV collagen).

Results: We cultured the P. lutzii in a chemically defined media without $\mathrm{Cu}$ and Fe. The fungus was then placed in contact with different ECM components and adhesion was evaluated. A significant increase in binding to all ECM components was observed when the fungus was cultured without $\mathrm{Cu}$; which might be related to some adhesins expression. A proteomic assay was developed and revealed 39 proteins expressed that are involved in processes such as virulence, protein synthesis, metabolism, energy, transcription, transport, stress response and the cell cycle when the fungus was interacting with the ECM components. The up-regulated expression of two important adhesins, enolase and 14-3-3, was observed at the fungal cell wall during the interaction with the ECM components, indicating the role of these proteins in the Paracoccidioides-host interaction.

Conclusions: This study is important for determining prospective proteins that may be involved in the interaction of Paracoccidioides with a host. Understanding the adaptive response to different growth conditions, elucidating the processes of adhesion and cell invasion, and identifying the proteins that are differentially expressed during the fungus-host interaction may help elucidate mechanisms used for survival and growth of Paracoccidioides in various human tissues.
\end{abstract}

Keywords: Paracoccidioides spp, Copper, Adhesion, Protein expression, Paracoccidioidomycosis

\section{Background}

Paracoccidioides lutzii, a specie from a complex genus [1-4], are dimorphic fungi and the etiologic agents of paracoccidioidomycosis (PCM), which is the most important systemic mycosis in Latin America [5]. Paracoccidioides is a notably versatile pathogen, with the ability of infecting numerous systems and organs of the human body,

\footnotetext{
* Correspondence: giannini@fcfar.unesp.br

'Departamento de Análises Clínicas, Faculdade de Ciências Farmacêuticas, UNESP - Univ Estadual Paulista, Laboratório de Micologia Clinica, Rodovia Araraquara-Jaú, Km 1, Araraquara, SP, Brazil

Full list of author information is available at the end of the article
}

because it has developed mechanisms that enable adherence and invasion of host tissues [6].

The Paracoccidioides species initiates host infection by adhering to components of the extracellular matrix (ECM); this adherence is mediated by a variety of adhesins on the fungal surface, with component recognition of adhesive matrix molecules, which plays an important role in the regulation of cell adhesion, differentiation, migration and proliferation [7]. Some Paracoccidioides adhesins have been described and are included in microorganism strategies of evading the immune system and ensuring survival in hosts. Adhesion is closely associated 
with the transcriptional control of several regulatory pathways that control the synthesis of these molecules. These pathways are activated in response to various conditions, such as nutrient limitation [8], which is vital for any pathogen.

To successfully colonize a host, Paracoccidioides must initially adhere to host tissues and simultaneously obtain essential nutrients for growth and survival. Iron $(\mathrm{Fe})$ and copper $(\mathrm{Cu})$ are required for survival, primarily due to their roles as cofactors for many essential metabolic functions. $\mathrm{Cu}$ is an essential micronutrient for all biological systems, with multiple proteins requiring one or more atoms of $\mathrm{Cu}$ to achieve the appropriate structure and function. To prevent the consequences of $\mathrm{Cu}$ deficiency, living organisms have evolved molecular mechanisms that regulate the uptake, intracellular traffic, storage and efflux of $\mathrm{Cu}$. Some of the cellular responses to variations in $\mathrm{Cu}$ levels are related to changes in the expression of genes encoding the molecular components of $\mathrm{Cu}$ metabolism. $\mathrm{Cu}$ serves as a catalytic and structural cofactor for enzymes involved many processes, including energy generation, $\mathrm{Fe}$ acquisition, oxygen transport and cellular metabolism [9]. Both the host and fungi have developed sophisticated strategies for acquiring the metals, even under conditions of limited availability. Several homeostatic mechanisms have been demonstrated in fungi, guaranteeing the maintenance of sufficient concentrations of $\mathrm{Cu}$ for cell growth without causing damage. Additionally, posttranslational mechanisms, such as the intracellular trafficking of $\mathrm{Cu}$ transporters, have been identified in mammals. In these organisms, $\mathrm{Cu}$ homeostasis is also mediated by the transcriptional regulation of genes involved in $\mathrm{Cu}$ acquisition, mobilization, and sequestration $[10,11]$.

During the infection process, the levels of free Fe and $\mathrm{Cu}$ are significantly reduced; the acquisition of these nutrients is related to a higher adaptive process that is important for microorganism virulence, as demonstrated in several organisms. In Candida albicans, increased gene expression was observed during Fe privation related to virulence, such as secreted hydrolase genes [12]. Similarly, mutations in the genes involved in Fe capture, such as the Fe oxidase gene in C. albicans [13] and the Fur gene from Helicobacter pylori [14], rendered these microorganisms incapable of colonizing host tissues and causing infection. In Cryptococcus neoformans, the increased expression of $\mathrm{Cu}$ transporters is related to the dissemination of the species in the host meninges [15]. In Paracoccidioides, low Fe conditions have been associated with fungal susceptibility to the antimicrobial action of monocytes [16]. The administration of exogenous Fe results in an increased fungal load in mouse tissues infected with Paracoccidioides [17].

Proteomic methods have been used to study the biology of Paracoccidioides. Historically, studies have focused on dimorphism and the characterization of single or a few protein targets in Paracoccidioides species [18-20], with the obtained information constituting a useful resource for studying the dimorphism of Paracoccidioides [21]. Parente et al. [17] used 2-DE to identify proteins related to Paracoccidioides survival in a Fe-deficient environment. They discovered that, during Fe starvation, fungi use the glycolytic pathway to obtain energy instead of the oxidative pathway, which is dependent on enzymes containing Fe-S groups. In addition, those authors identified activation of the Fe uptake systems as an indispensable survival mechanism required by the fungus in this type of environment [17]. Vallejo et al. [22] studied the secretome of Paracoccidioides with regards to the fungal extracellular vesicles that are able to cross the cell wall and transport molecules that facilitate nutrient acquisition, cell defense, and modulation of the host defense machinery. In another study, those authors determined that Paracoccidioides shared secreted proteins among Histoplasma capsulatum, C. neoformans and Saccharomyces cerevisiae [23]. The mycelia and yeast cell secretomes of Paracoccidioides have also revealed that many proteins do not use the classical secretory pathway, while many other proteins likely exerted other activities, once secreted. Paracoccidioides data has indicated that it uses non-classical targeting mechanisms to direct protein export and also that it has molecules that can function as virulence factors [24]. De Arruda Grossklaus et al. [25] also studied the oxidative stress response of Paracoccidioides using proteomic analysis.

Our aim was to analyze the adhesion of Paracoccidioides lutzii ( $\mathrm{Pb} 01$ isolate) in $\mathrm{Cu}$ and $\mathrm{Fe}$ depleted conditions, while also determining the proteins that may be involved in the interaction among Paracoccidioides and ECM components that lead to an increase in fungal adhesion when the fungus was deprived of $\mathrm{Cu}$. These proteins are involved in distinct biological processes, such as the cell cycle, stress response and Fe transportation; additionally, several proteins have been described as virulence factors and possible candidates for Paracoccidioides virulence. The results of this study provide new knowledge that may facilitate strategies used by Paracoccidioides to successfully parasitize host tissues, leading to the development of paracoccidioidomycosis.

\section{Results}

\section{Adhesion of Paracoccidioides lutzii to ECM components} during $\mathrm{Cu}$ and $\mathrm{Fe}$ depletion

Following incubation in MVM without $\mathrm{Cu}$ (MVM-W-Cu medium), the $P$. lutzii yeast phase presented a significant increase $(\mathrm{p}<0.05)$ in adhesion (Figure 1$)$ in the presence of all tested ECM components (laminin, fibronectin, and types I and IV collagen), while in MVM without Fe (MVM-W-Fe), we observed a significant decrease 


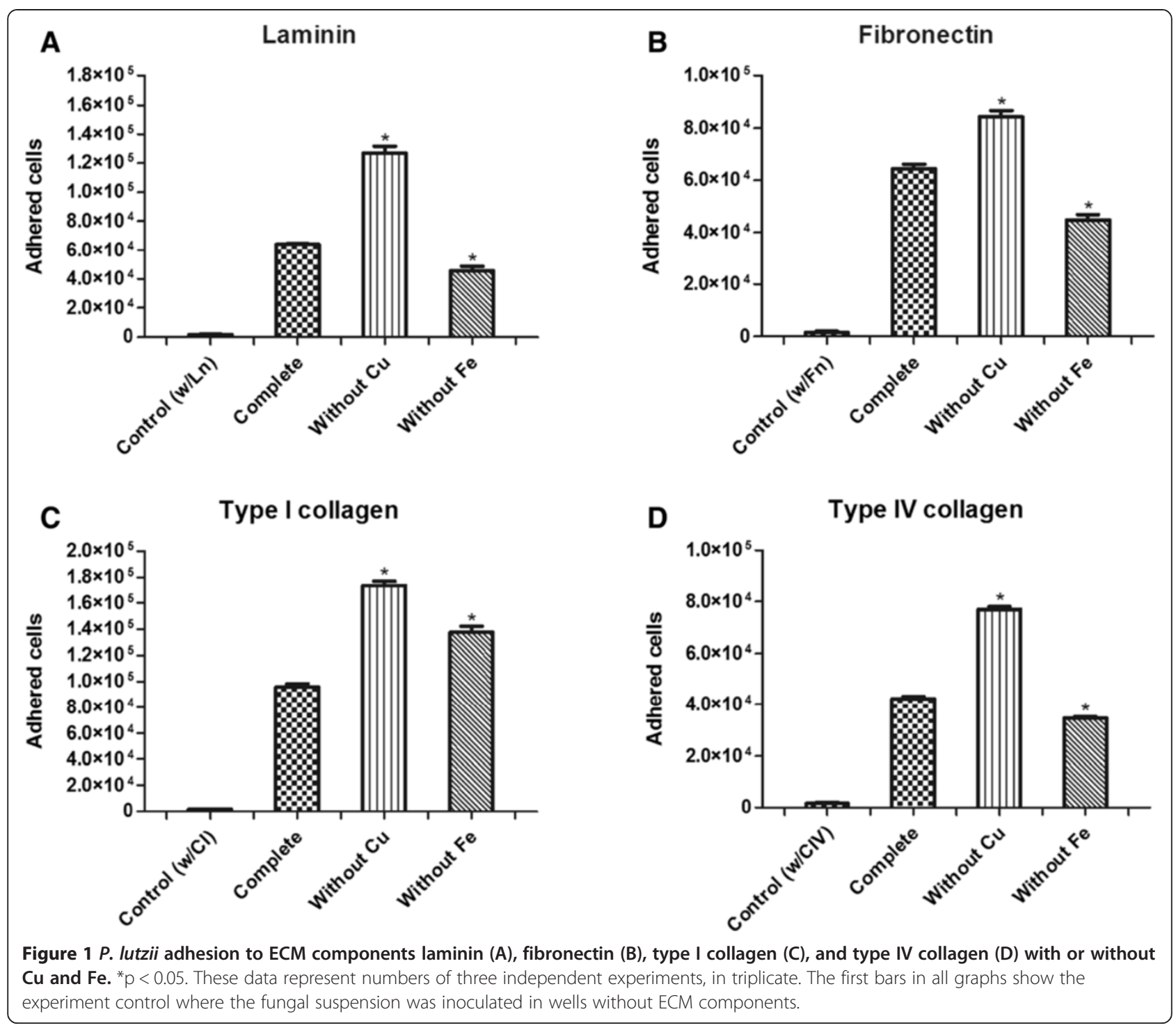

$(\mathrm{p}<0.05)$ in adhesion in the presence of laminin, fibronectin and type IV collagen and an increase in the presence of type I collagen, but this increase was significantly lower $(\mathrm{p}<0.05)$ than the increase observed under $\mathrm{Cu}$ depletion.

Adhesin expression profile during $\mathrm{Cu}$ and Fe depletion in the presence of ECM components

The expression of genes that encoded most of the known Paracoccidioides adhesins during the interaction with the host ECM components (laminin, fibronectin and types I and IV collagen) were analyzed. We used real-time PCR to determine whether the metal depletion modulated adhesin expression. As shown in Figure 2, we observed that different micronutrient depletion conditions led to different levels of adhesin expression.

$\mathrm{Cu}$ depletion led to increased expression of the main adhesins, except for gp43 and malate synthase (MLT), whereas Fe depletion led to decreased expression in all studied adhesins. These effects corroborate the results of the adhesion experiments and revealed the importance of these proteins to the Paracoccidioides-host interaction, in which increased and decreased adhesion may be related to adhesin expression.

Immunogold expression analysis of enolase and 14-3-3 proteins in $P$. lutzii yeast cells during interaction with ECM components after micronutrient depletion

Real-time PCR analysis revealed higher expression levels of two adhesins, enolase and 14-3-3, under conditions of $\mathrm{Cu}$ depletion and in the presence of the different ECM components. Thus, we explored the subcellular location of these proteins using anti-enolase and anti-14-3-3 polyclonal antibodies in combination with immunoelectron microscopy (IEM) to confirm the differential expression of these proteins during the interaction of $P$. lutzii with the different ECM components (Figures 3 and 4). P. lutzii yeast 

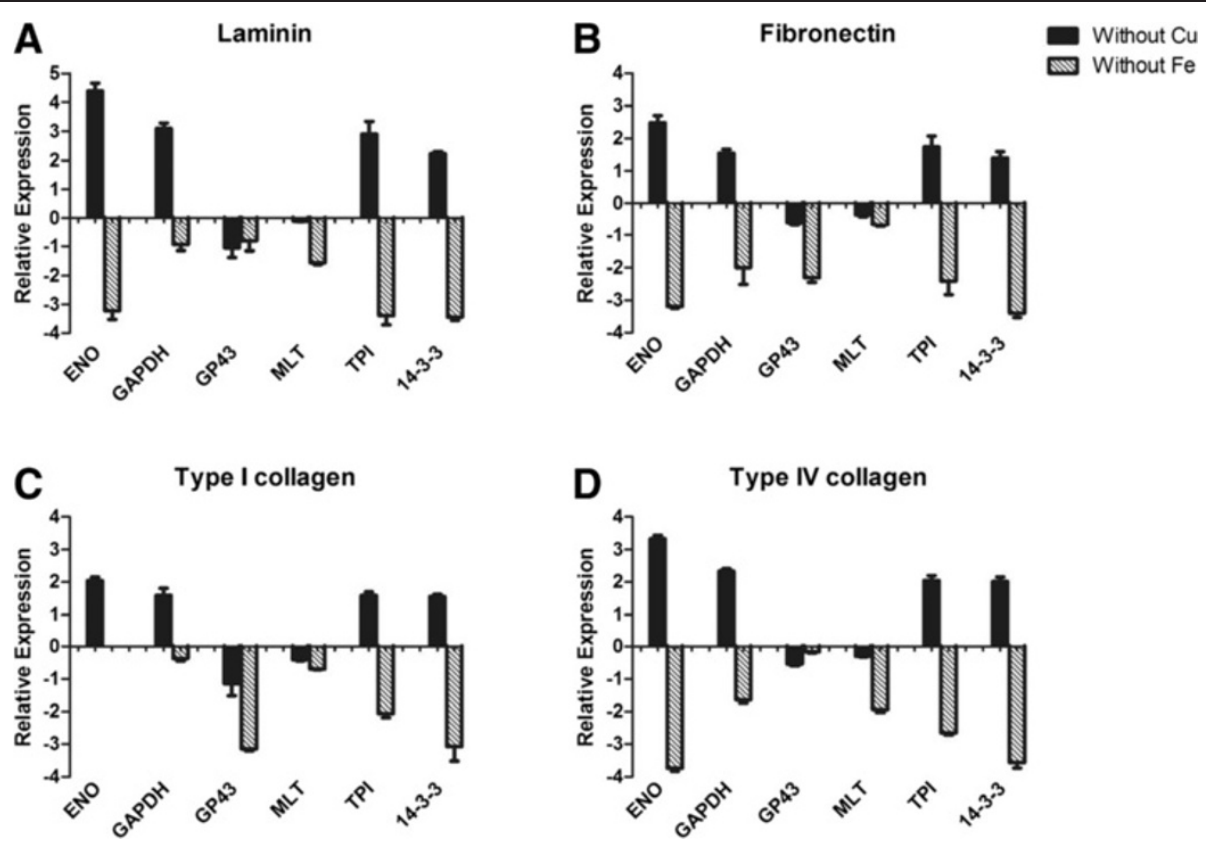

Figure 2 P. lutzii adhesins expression profile during interaction with laminin (A), fibronectin (B), collagen type I (C), and collagen type IV (D) after Cu and Fe depletion.
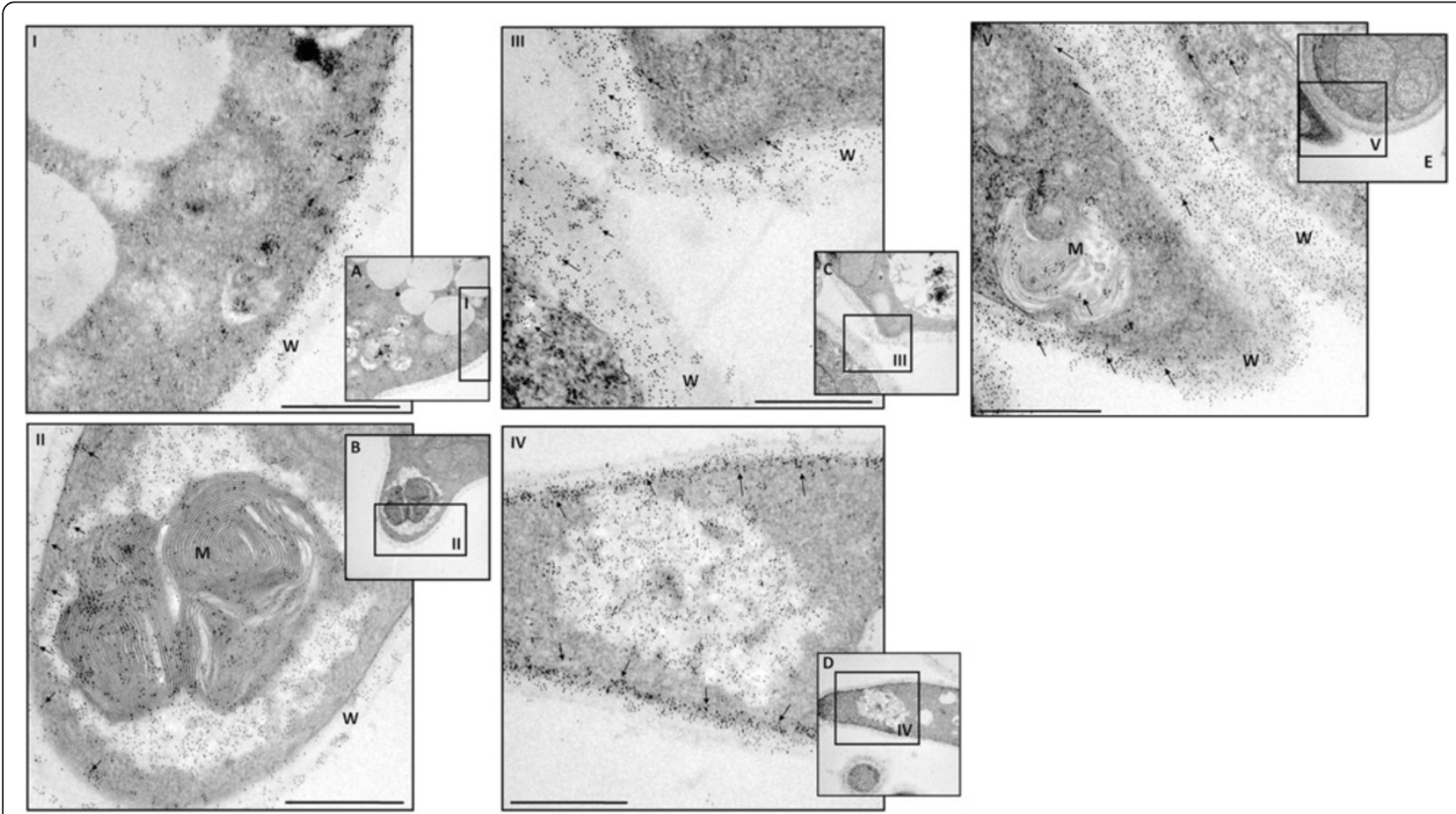

Figure 3 IEM detection of enolase in P. lutzii yeast cells without $\mathrm{Cu}(\mathrm{A})$, and without $\mathrm{Cu}$ add laminin (B), fibronectin (C), type I collagen (D), or type IV collagen (E). The arrows indicate enolase labeled with gold particles. Bars: $0.07 \mu \mathrm{m}$. W: cell wall; M: mitochondria; V: intracellular vesicles. I, II, III, IV and V indicate which image region has been increased in the microscope. 
cells with and without $\mathrm{Cu}$ in contact with all the ECM components were processed by post embedding with gold particles. The immunocytochemistry assays revealed a ubiquitous distribution of the gold particles in all conditions, but we observed that, when the fungus was grown under simulated infection conditions, there was an increased expression of enolase and 14-3-3 (indicated with arrows in Figures 3 and 4) in the fungal cell wall. A quantitative analysis was developed by counting the number of expressed enolase and 14-3-3 proteins in the fungal cell wall and a real increase of protein expression occurred in the cell wall during its interaction with all ECM components (Figure 5). These results showed that these proteins, when interacting with the host structures, are recruited to the cell wall and may be used during this interaction, as shown by da Silva et al. [26] and Marcos et al. [27].

\section{Paracoccidioides lutzii protein expression identification by mass spectrometry during $\mathrm{Cu}$ deprivation in the presence of different ECM components}

The protein profile of $P$. lutzii grown in an environment depleted of $\mathrm{Cu}$ was used as a master gel for comparison after contact with the ECM components (laminin, fibronectin, type I and type IV collagen). Based on these analyses, differentially expressed proteins were selected for identification by mass spectrometry (MS), as well as the results of the expression analysis. The results indicate that the fungus uses an arsenal of proteins during its interaction with the host ECM components (Figure 6). This arsenal is composed of proteins that are related to different cell processes (Figure 7) and an extensive number of proteins that may be involved with the interaction between the fungus and the host. Additionally, some of the identified proteins are involved in metabolism and the transport of micronutrients, such as Fe and Zinc $(\mathrm{Zn})$, revealing the adaptation of the fungi to the environment. We also observed proteins that are involved in DNA repair and heat shock proteins that are induced as a response to the stress that this fungus was submitted to during $\mathrm{Cu}$ starvation. The contact of the fungus with different ECM components led to the different responses, forcing the pathogen to adapt to the environment. The results found during this interaction with each of the different ECM components vary and these proteins can be shared to interact with the different components. We observed that 19 proteins are shared during the interaction with all ECM components, while 21 are common between the interaction of $P$. lutzzi with Lm and Fn, 19 with Lm and CI, 21 with Lm and CIV, 22 with Fn and CI, 22 with Fn and CIV and 22 with CI and $\mathrm{CIV}$, as summarized in Figure 8. Comparative proteomic analysis with $P$. lutzii maintained in a medium supplemented with $\mathrm{Cu}$ warrants future study.

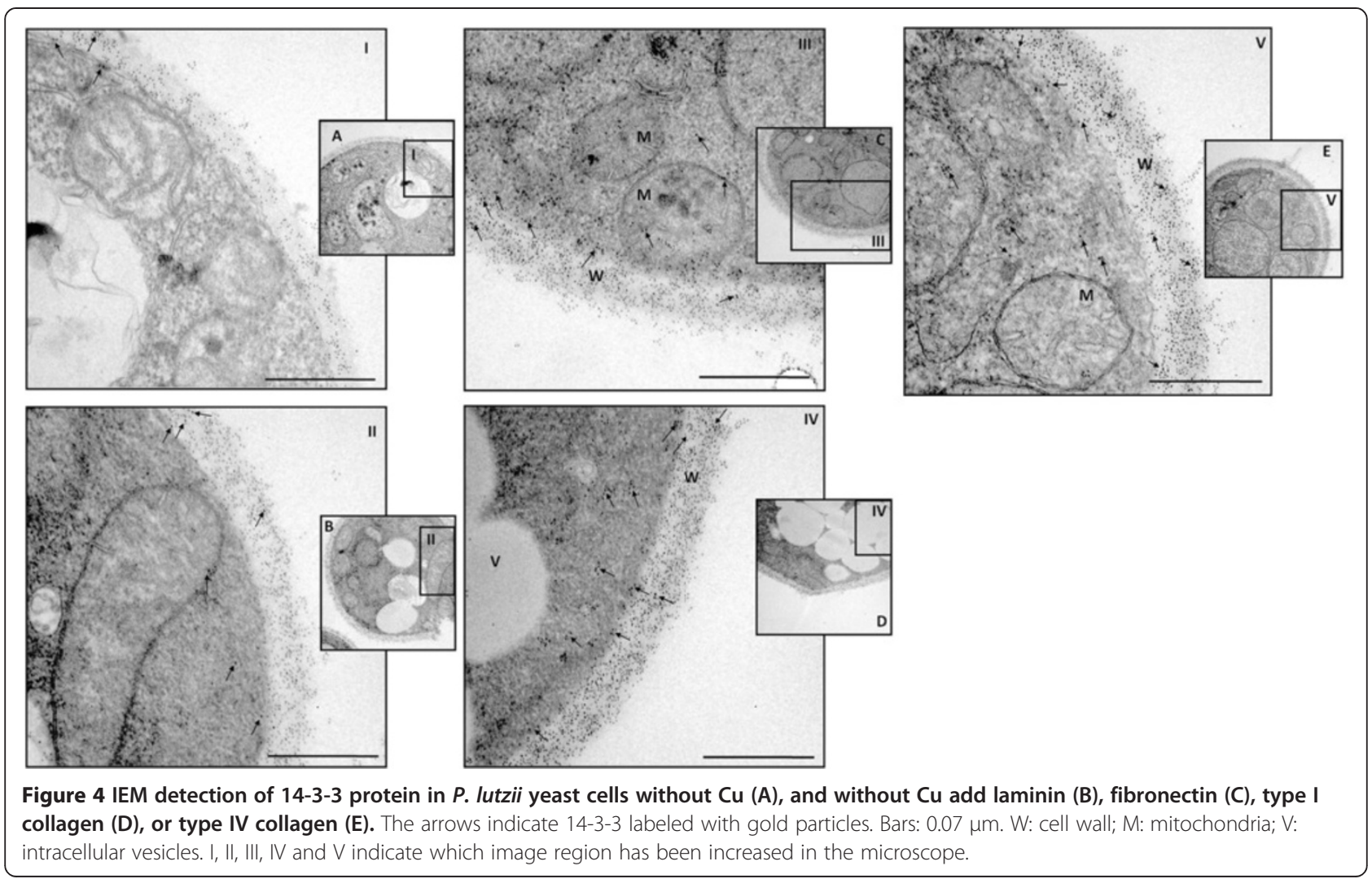




\section{A Enolase expression in P. lutzii cell wall}

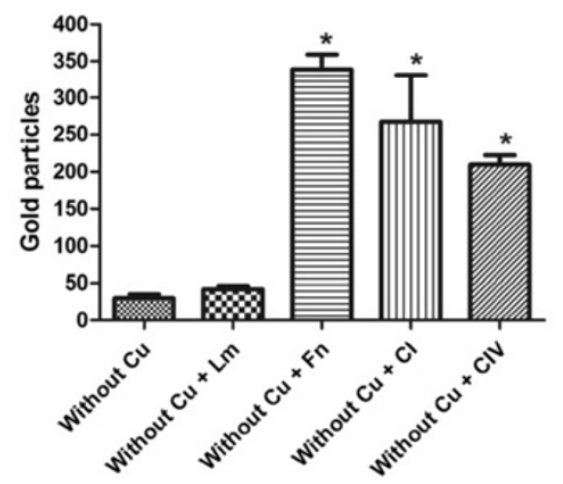

B 14-3-3 expression in P. lutzii cell wall

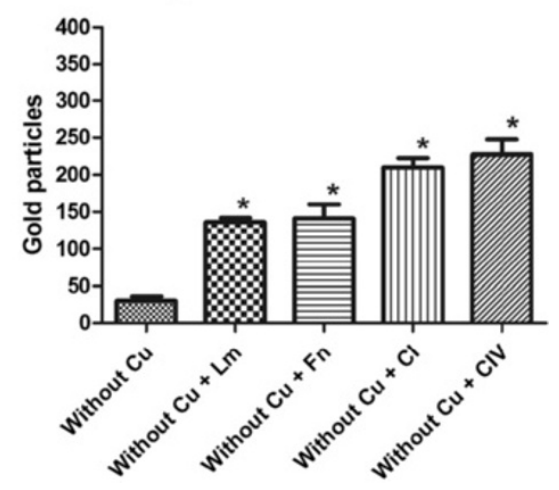

Figure 5 Quantitative analyses of expressed A) enolase and B) 14-3-3 proteins during the interaction with ECM components.

Real-time PCR to validate 2D-E assay results

Six of the proteins identified when using the proteomic approach were chosen to validate the regulation of gene expression by real-time PCR. The chosen genes for this evaluation were enolase, 14-3-3, aldolase, GAPDH, serine/ threonine-protein kinase CBK1, siderophore-Fe transporter ENB1 and vesicle-mediated transport-related protein. These genes were selected based on their importance in interactions between Paracoccidioides and the host. This analysis confirmed a regulation of the expression of the proteins identified using proteomics and showed that $\mathrm{Cu}$ depletion led to a regulation at the transcriptional levels of the proteins, since the observed gene expression levels were totally correspondent with the protein expression levels (Figure 9). Table 1 summarizes these results.

\section{In silico analysis of putative proteins identified in 2D gel analysis}

We observed 8 proteins that had unknown functions and made functional inferences using in silico analysis. It is known that surface proteins are important for Paracoccidioides pathogenesis, so we performed in silico analysis to identify adhesin-like proteins using FaaPred software, which predicts fungal adhesins and adhesin-like proteins. This analysis predicted 2 proteins as adhesin-like proteins (Table 2), revealing interesting candidates for further studies of the protein relationships with Paracoccidioides virulence.

The expression of these adhesin-like proteins was evaluated using real-time PCR during the interaction of P. lutzii with the host ECM components (Figure 10). These results demonstrated that proteomic assays could identify unknown molecules that may be related to the adhesion of Paracoccidioides. These results allow for the identification of some adhesin-like proteins that may be important for fungal adhesion to different ECM components in different sites of the host organism and determining the contributions of these proteins to fungal establishment.

\section{Discussion}

All organisms most likely depend on efficient metal transport systems for survival. Fe and $\mathrm{Cu}$ are particularly important metals because they participate in vital reactions and are both cofactors of many metabolic enzymes and are essential nutrients for the maintenance of life [28]. In excess, these metals can be toxic; however, disturbances to the $\mathrm{Fe}$ and $\mathrm{Cu}$ levels can have serious effects on cellular metabolism, growth and development [29]. $\mathrm{Cu}$ exists as a trace element, and is found in low concentrations in living organisms. However, $\mathrm{Cu}$ is an important catalytic cofactor that guides several important biological processes that are essential for life. $\mathrm{Cu}$ regulates changes in protein structure, catalytic activity and protein-protein interactions. In this manner, it controls a varied series of biochemical events; $\mathrm{Cu}$ may modulate critical fungal virulence factors [9].

The importance of our work lies precisely in the fact that Paracoccidioides is a facultative intracellular pathogen. Because of this characteristic, any external changes in the intracellular environment can directly influence the pathogenicity of this organism. Additionally, the period evaluated and ECM components used in this work (laminin, fibronectin and collagen) are essential in the initial interaction of the pathogen with the host, thus any change of homeostasis (such as deprivation of micronutrients) would have a direct impact on this initial interaction and, consequently, virulence.

In our study, the depletion of $\mathrm{Cu}$ altered the adhesion pattern of Paracoccidioides to ECM components. There was a significant $(\mathrm{p}<0.05)$ increase in adhesion to all ECM components, which was different from what we observed for Fe. Fe depletion led to a significant decrease in adhesion, corroborating the results of Parente et al. [17], who demonstrated that Fe supplementation increased the susceptibility of mice to Paracoccidioides infection. Using real-time PCR, we observed that the depletion of these metals altered the expression patterns of adhesins, which 


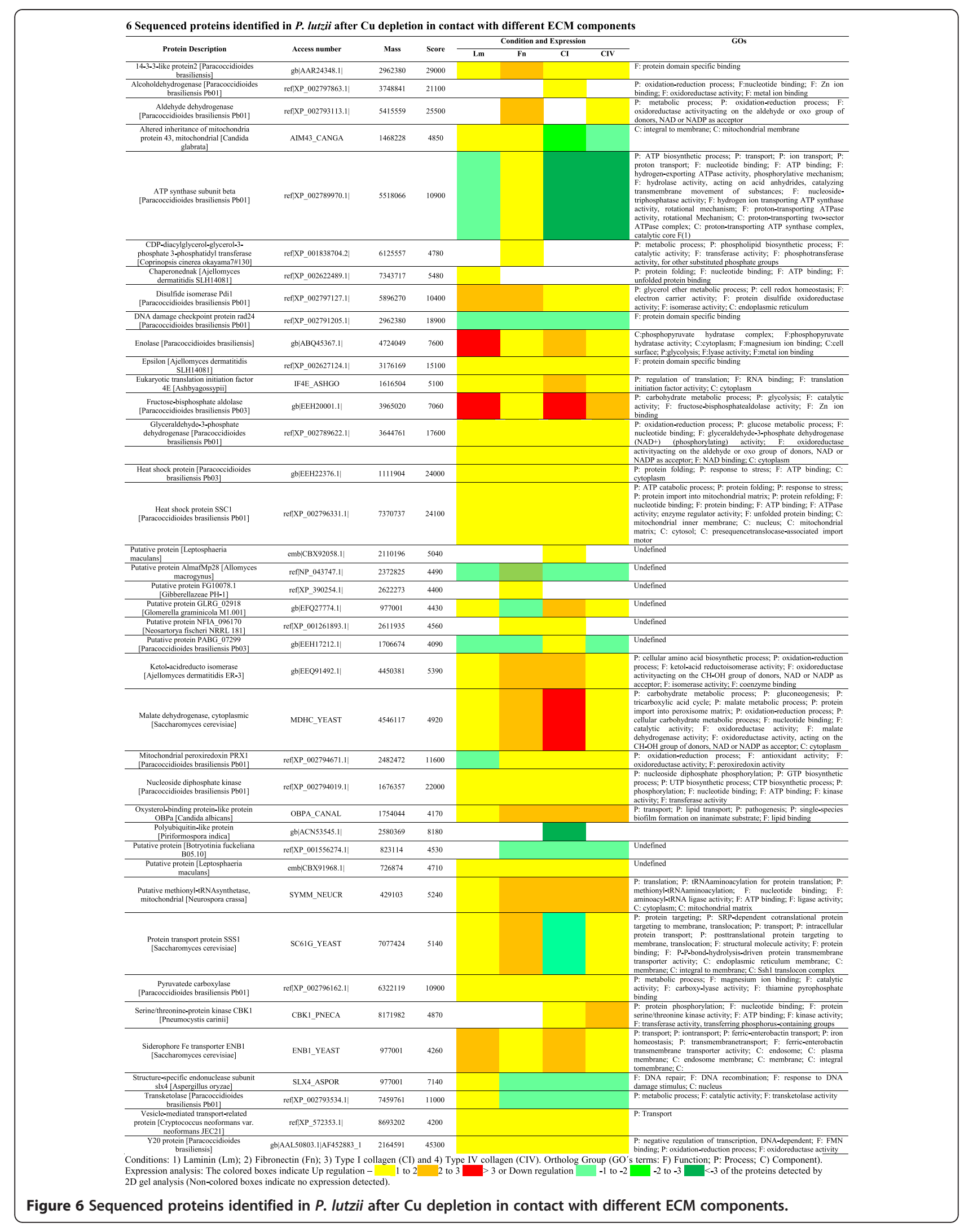




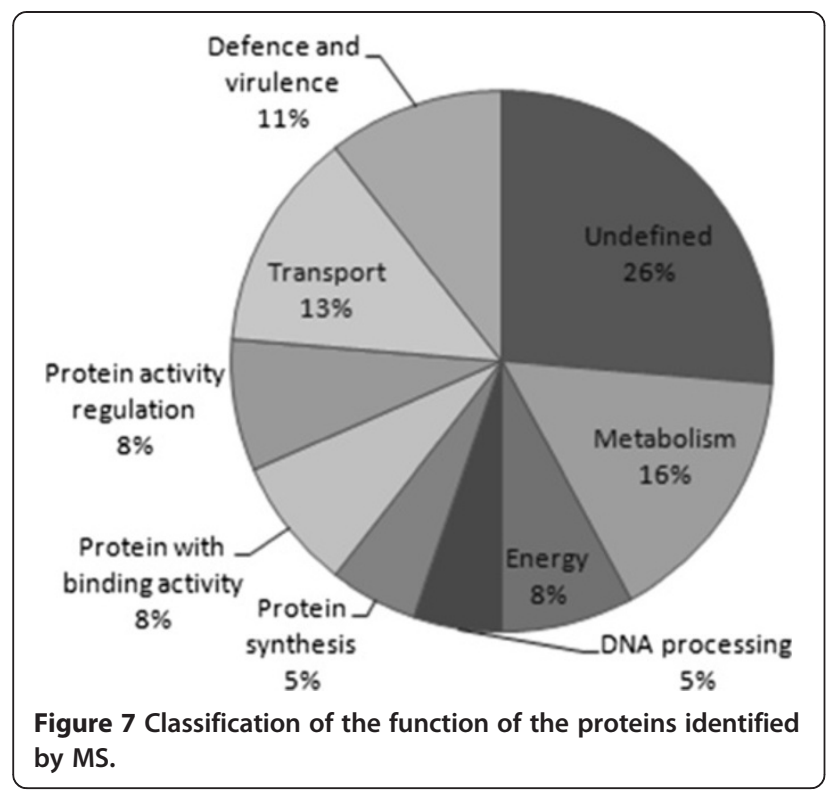

are important components in the Paracocccidioides-host interaction. When the fungus was grown in $\mathrm{Cu}$-depleted conditions, overexpression of genes encoding adhesins was observed, whereas down-regulation of the same genes was observed during Fe-depletion. Complementing these results by using immunogold analysis, we clearly observed an increased expression of two important adhesins, enolase and 14-3-3 protein, when the fungus was in an environment depleted of $\mathrm{Cu}$ and in contact with different ECM components. In addition, we observed that this increase occurred in the fungus cell wall, suggesting that the intensification of adhesion may be attributable to the great quantity of these adhesins in the fungal cell wall.

The identification of proteins involved in the initial phase of host-fungus interactions is very important and can result in the identification of potential drug targets for future therapeutic research to prevent the early infectious process. The 2-DE technique was used in this study to determine proteins that may be involved in the interaction among Paracoccidioides and ECM components when the fungus was deprived of $\mathrm{Cu}$, leading to an increase in the adhesion of the fungi.

Our goal with the proteome was to understand what makes the fungus increase its capacity to adhere to all ECM components after $\mathrm{Cu}$ deprivation, which is why our main control was only the fungi maintained without $\mathrm{Cu}$. All of the proteins identified in these results are expressed during $\mathrm{Cu}$ depletion, but they suffer modifications in expression because of the contact of the fungi with the host.

Our proteomic assays identified 39 proteins expressed by the fungi after $\mathrm{Cu}$ depletion and during its interaction with the ECM components. These results contribute to our knowledge of the molecular arsenal used by Paracoccidioides to adhere, invade and cause systemic mycosis.

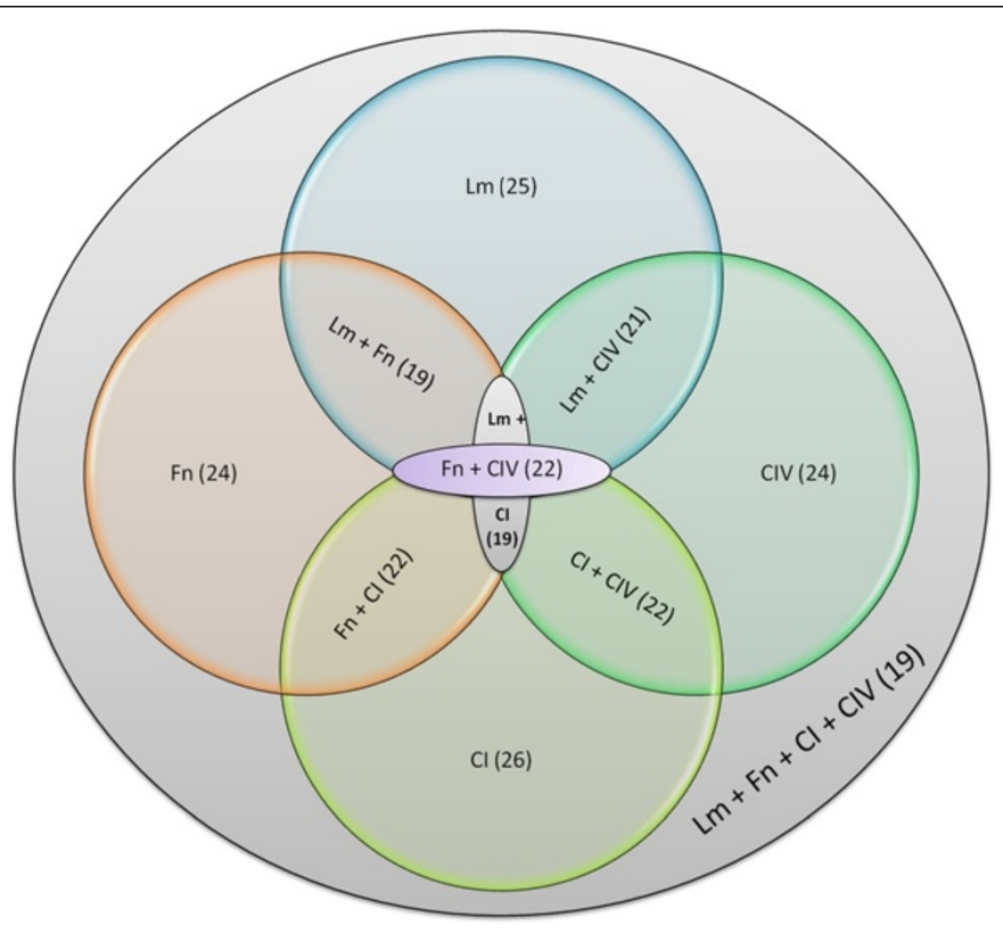

Figure 8 Proteins identified by Venn diagram, which interact with the different ECM components: overview of the number of the proteins differentially expressed by $P$. lutzii during its interaction with the host components. 
A

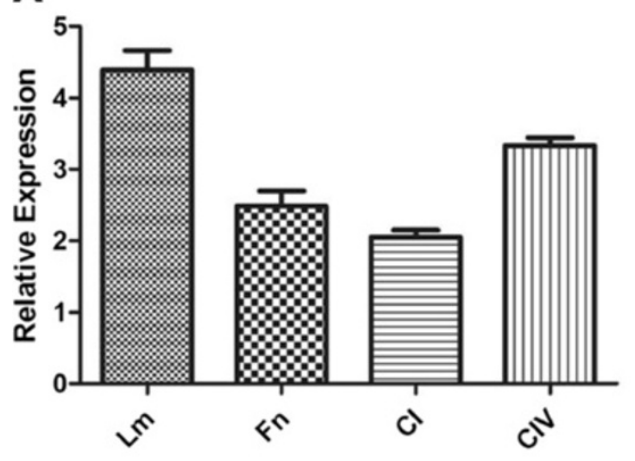

C

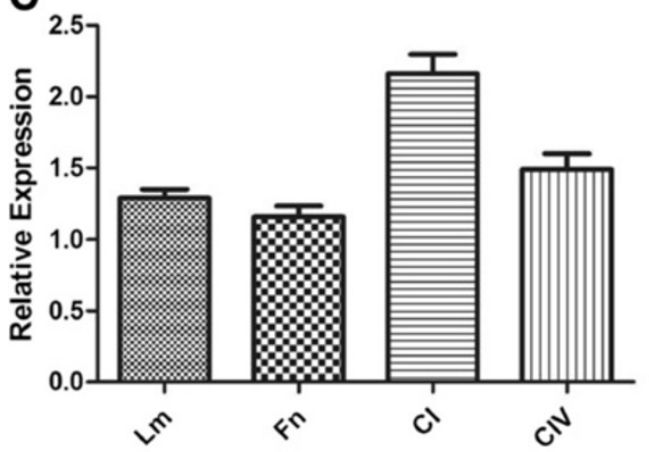

E

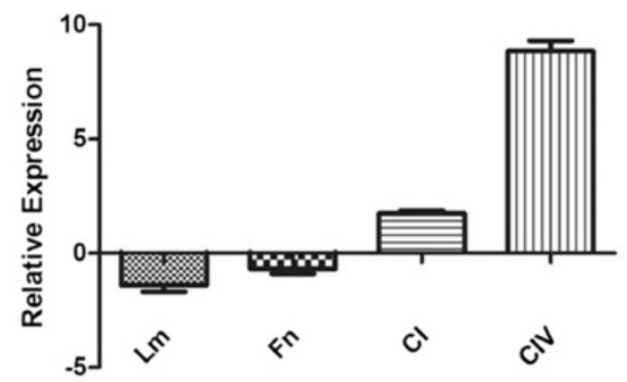

G

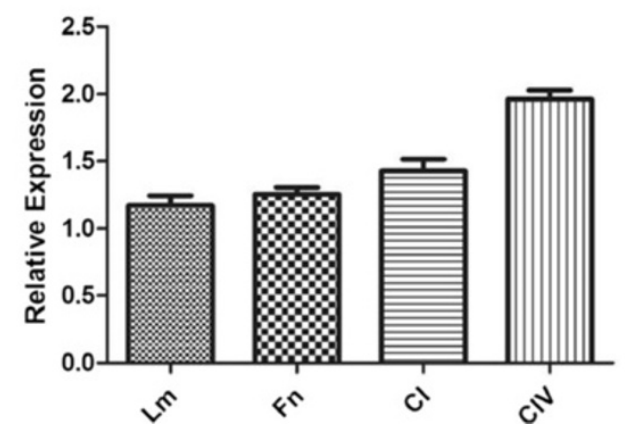

B

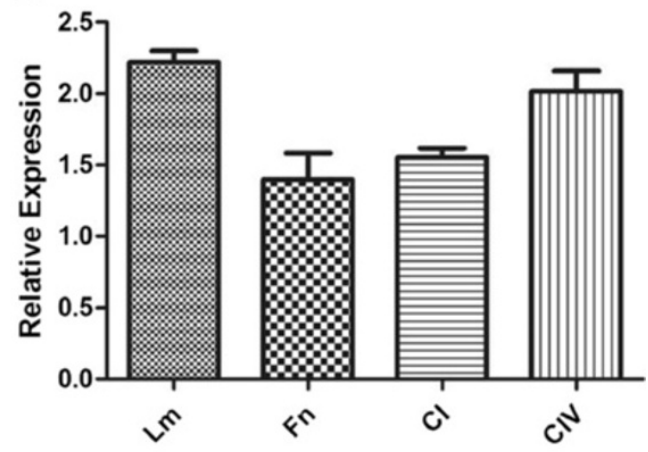

D

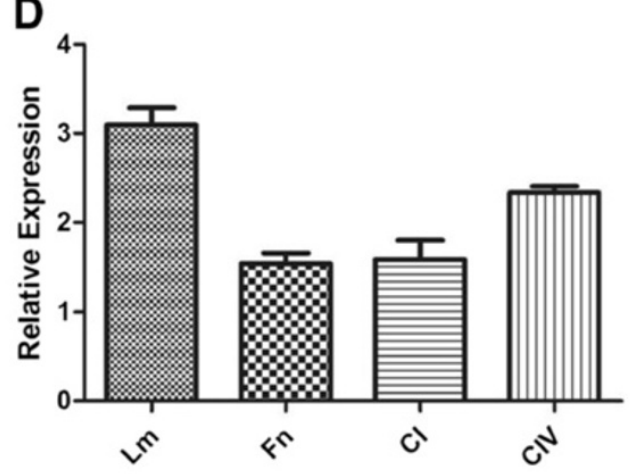

F

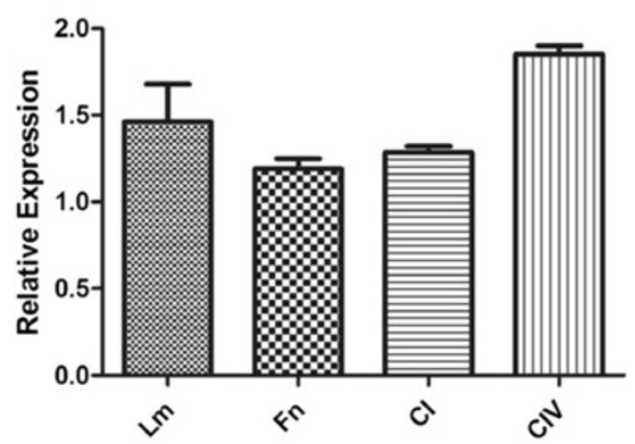

Figure 9 Quantification of differentially expressed genes and proteins without $\mathrm{Cu}$ in contact with the different ECM components using Real Time PCR. A) Enolase; B) 14-3-3; C) Aldolase; D) GAPDH; E) Serine/threonine-protein kinase (BK1; F) Siderophore Fe transporter ENB1; G) Vesicle-mediated transport-related protein. 
Table 1 Comparison on the expression levels of the identified proteins and its coding genes

\begin{tabular}{|c|c|c|c|c|c|c|c|c|}
\hline & \multicolumn{4}{|c|}{ Proteomics } & \multicolumn{4}{|c|}{ Real-time PCR } \\
\hline & $\mathrm{Lm}$ & Fn & $\mathrm{Cl}$ & CIV & $\mathrm{Lm}$ & Fn & $\mathrm{Cl}$ & CIV \\
\hline ENO & $\uparrow \uparrow \uparrow$ & $\uparrow$ & $\uparrow$ & $\uparrow \uparrow$ & $\uparrow \uparrow \uparrow$ & $\uparrow$ & $\uparrow \uparrow$ & $\uparrow$ \\
\hline $14-3-3$ & $\uparrow \uparrow$ & $\uparrow$ & $\uparrow$ & $\uparrow$ & $\uparrow$ & $\uparrow \uparrow$ & $\uparrow$ & $\uparrow$ \\
\hline ALD & $\uparrow$ & $\uparrow$ & $\uparrow \uparrow$ & $\uparrow$ & $\uparrow \uparrow \uparrow$ & $\uparrow$ & $\uparrow \uparrow \uparrow$ & $\uparrow \uparrow$ \\
\hline GAPDH & $\uparrow \uparrow \uparrow$ & $\uparrow$ & $\uparrow$ & $\uparrow \uparrow$ & $\uparrow$ & $\uparrow$ & $\uparrow$ & $\uparrow$ \\
\hline CBK1 & & & $\uparrow$ & $\uparrow \uparrow$ & $\downarrow$ & $\downarrow$ & $\uparrow$ & $\uparrow \uparrow \uparrow$ \\
\hline ENB1 & $\uparrow \uparrow$ & $\uparrow$ & $\uparrow \uparrow$ & $\uparrow$ & $\uparrow$ & $\uparrow$ & $\uparrow$ & $\uparrow$ \\
\hline VES & $\uparrow$ & $\uparrow$ & $\uparrow$ & $\uparrow$ & $\uparrow$ & $\uparrow$ & $\uparrow$ & $\uparrow \uparrow$ \\
\hline
\end{tabular}

Upregulation is represented by $\uparrow$ and downregulation is represented by $\downarrow$ and the number of arrows indicates the identified levels of expression ( 1 arrow - 1 to 2, 2 arrows - 2 to 3 and 3 arrows - 3 or more or less folds expressed when compared with the control).

Among the identified proteins, some of them were already identified as being important to the interaction of Paracoccidioides spp. with the host and could be associated with dissemination of the infection. These proteins are 14-3-3, enolase, aldolase and glyceraldehyde3 -phosphate dehydrogenase; all of which are currently described as adhesins [26,27,30-32]. These adhesins have their expression up-regulated while interacting with the host with all ECM components. These results, once again, reveal the importance of these molecules in the interaction of $P$. lutzii with the host. The experiment indicates that, during $\mathrm{Cu}$ starvation, these molecules are maintained at basal levels of expression, but contact with the host signaled the fungus to increase the expression of these proteins to adhere to the host and, from the host, obtain the necessary $\mathrm{Cu}$ for maintenance. With these results, we can understand how the fungus uses its protein arsenal to adapt to the host and have success during the infection process.

Increased enolase expression was verified; this protein was recently described as a fibronectin ligand related to Paracoccidioides adhesion and is considered a virulence factor [31]. Recent studies have shown that enolase has different distributions and biological functions [33] and is expressed at different sites in eukaryotes and prokaryotes with distinct biological functions, such as the laminin ligand in Staphylococcus aureus [34] and enolase binding of human plasminogen in Trichomonas vaginalis [35], Streptococcus pneumoniae [36], Leishmania mexicana [37] and Fasciola hepatica [38]. In our study, enolase was differentially expressed when the fungus was in contact with all of the ECM components, not only fibronectin, as previously described by Donofrio et al. [30]. However, it is worth noting that the strain used in the latter work was a Paracoccidioides brasiliensis strain named $\mathrm{Pb} 18$, which could be an important factor for further investigation [31]. Nevertheless, data from Nogueira et al. [20] also demonstrated binding of enolase to laminin and type I collagen, corroborating the findings of this study. Moreover, data from Nogueira et al. [20] also indicates that enolase is an important Paracoccidioides molecule used during its interaction with the host. The expression of this protein in this present study corroborates earlier data suggesting that Paracoccidioides enolase can be used to adhere to and, perhaps, invade host cells through an interaction with human plasminogen $[31,33,36,38]$. The ability to bind plasminogen has been associated with invasive properties in pathogenic microorganisms $[37,39,40]$ and can facilitate their penetration to the basement membrane and permit associations with fibronectin and laminin. Although Paracoccidioides is considered a facultative intracellular pathogen, fibronectin adhesin ligands can also mediate cellular invasion. Our electron microscopy results demonstrated an increase of enolase during the interaction between the fungus cell and the ECM components, mainly at the cell wall. These current results corroborate those of Marcos et al. [27], who reported a substantial increase of enolase in the cell wall during infection of pneumocytes (A549 cells), suggesting the importance of this protein in fungal adhesion to the host [41].

We also observed the overexpression of the 14-3-3 protein when the fungus was in contact with all of the ECM components studied. The 14-3-3 proteins are a family of highly conserved acidic dimeric proteins that have been implicated in a variety of cellular processes in eukaryotes [41-44]. In Paracoccidioides, a 30-kDa protein has been

Table 2 In silico analysis of sequenced putative proteins using the software FaaPred

\begin{tabular}{llll}
\hline Protein & Access number & Prediction & SVM Score \\
\hline Putative protein [Leptosphaeria maculans] & emb|CBX92058.1| & Adhesin & Non-adhesin \\
Putative protein AlmafMp28 [Allomyces macrogynus] & ref|NP_043747.1| & Non-adhesin & -1.7894963 \\
Putative protein FG10078.1 [Gibberellazeae PH-1] & ref|XP_390254.1| & Adhesin & -1.0139011 \\
Putative protein GLRG_02918 [Glomerella graminicola M1.001] & gb|EFQ27774.1| & Non-adhesin & -0.63979878 \\
Putative protein NFIA_096170 [Neosartorya fischeri NRRL 181] & ref|XP_001261893.1| & Non-adhesin & -1.5268407 \\
Putative protein PABG_07299 [Paracoccidioides brasiliensis Pb03] & gb|EEH17212.1| & Non-adhesin & -1.3347091 \\
Putative protein [Botryotinia fuckeliana B05.10] & ref|XP_001556274.1| & Non-Adhesin & -1.283864038 \\
Putative protein [Leptosphaeria maculans] & emb|CBX91968.1| & &
\end{tabular}


A Hypothetical protein (emb|CBX92058.1)

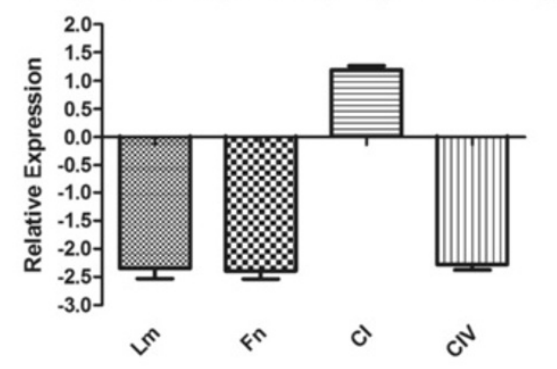

B Hypothetical protein (gb|EFQ27774.1)

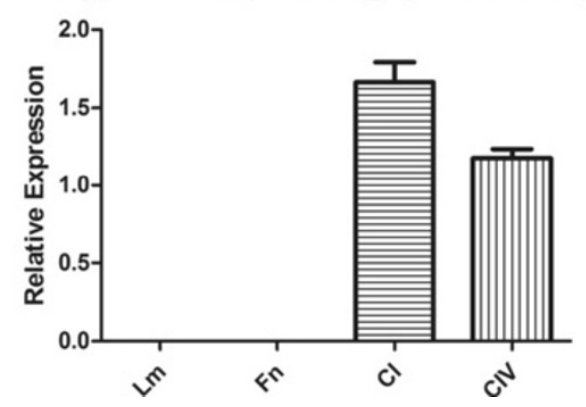

Figure 10 Quantification of predicted adhesins differentially expressed without $\mathrm{Cu}$ in contact with the different ECM components using Real Time PCR. A) Putative protein [Leptosphaeria maculans] (emb|CBX92058.1|), B) Putative protein GLRG_02918 [Glomerella graminicola M1.001] (gb|EFQ27774.1|).

identified and characterized as a 14-3-3 protein that causes structural modification of polymerized actin microfilaments and cytokeratin, induces apoptosis when interacting with epithelial cells and is capable of binding to laminin $[45,46]$. In addition, da Silva et al. [26] demonstrated that, during when Paracoccidioides interacted with A549 cells, an apparent increase of the 14-3-3 protein on the cell wall of the fungus occurs, suggesting that this protein may be involved in host-parasite interactions.

Glyceraldehyde-3-phosphate dehydrogenase (GAPDH) and fructose 1,6-biphosphate aldolase (FBA) (part of the glycolytic pathway) were observed to be overexpressed during the interaction of Paracoccidioides with all of the ECM components studied. Barbosa et al. [31] demonstrated that GAPDH from Paracoccidioides is able to bind to laminin, fibronectin and type IV collagen and the inhibition of this protein causes decreased adhesion rates of the fungus to epithelial cells [31]. FBA appears to be important in hostparasite interactions $[47,48]$. A FBA homologue was previously described as an immunogenic protein of Paracoccidioides [18]. Additionally, this fungus contains two genes encoding two different Class II FBAs. Phylogenetic analysis supports the concept of gene duplication for FBA genes, constituting a two-member family whose function could differ in the fungal cells. In addition, expression analysis performed using northern blot and RT-PCR indicated a differential expression for Pbfba1 and Pbfba2 in Paracoccidioides cells, suggesting distinct functions for both proteins [32]. An interesting and unsuspected feature observed during this present work is that both Paracoccidioides FBAs appeared to play roles in the fungal interaction with the host. PbFBA1 has immunogenic properties, as indicated by the fact that the native protein was recognized by the sera of infected patients [18].

Under conditions of $\mathrm{Cu}$ depletion, we observed an increase in the expression of ENB1, the enterobactin Fe transporter, a high-affinity siderophore in microbial systems. This increase may have occurred because most Fe- acquisition systems are $\mathrm{Cu}$ dependent, and $\mathrm{Cu}$ deficiency may force the fungi to use the siderophore system to acquire Fe from the culture media [49]. The siderophores are generally used by microorganisms in situations of low Fe concentrations. However, Froissard et al. [49] reported that ENB1 appears to be constitutively expressed in the plasma membrane of S. cerevisiae, and its expression is not affected by the substrate concentration.

Another protein that exhibited increased expression was CBK1, a serine/threonine protein kinase of the RAM signaling network. Cbk1p is similar to the human myotonic dystrophy kinase and is essential for normal morphogenesis in S. cerevisiae. It is involved in regulating cellular morphogenesis, polarized growth, and septum destruction. Cbk1p activity is regulated by both phosphorylation and specific localization; the protein relocates to the cytoplasm upon DNA replication stress [50]. Cbk1 has been previously implicated in regulating polarized morphogenesis, gene expression and cell integrity in S. cerevisiae and is also critical for heat shock and cell wall stress signaling. These results obtained using $S$. cerevisiae constitute the first evidence that Cbk1 kinase regulates MAPK-dependent stress signaling and provides mechanistic insight into Sdp1 phosphatase regulation via Bck2, a protein associated with the Pkc1-Mpk1 cell integrity pathway [51]. In C. albicans, Cbk1 is a daughter cell protein involved in cell wall degradation from the daughter side during cell separation [52]; recently, this protein was observed to be involved in C. albicans biofilm formation [53]. In this current work, we verified that $\mathrm{Cu}$ depletion promotes stress and cellular changes in the cell wall composition of Paracoccidioides. In addition, the increased expression of all previously described Paracoccidioides adhesins and the increased expression of kinases may suggest that remodeling of the Paracoccidioides cell wall could occur through activation of the RAM pathway. This mechanism should be investigated in future studies. 
The identification of a vesicle-mediated transport-related protein overexpressed during the interaction of Paracoccidioides with all of the ECM components is an interesting finding because Vallejo et al. [54] recently described the presence of these structures in Paracoccidioides, including antigenic molecules, that are recognized by total sera from PCM patients. Vallejo et al. [22] also described the proteomic analysis of extracellular vesicles and vesicle-free released proteins in Paracoccidioides and demonstrated that these vesicles carry different molecules, including virulence factors previously described for Paracoccidioides. It is important to emphasize that we observed molecules such as GAPDH, enolase, aldolase, 14-3-3 and malate dehydrogenase in the current study [23].

In our proteomic results, we also observed several putative proteins with currently unknown functions. Therefore, an in silico analysis was performed to identify sequences that may play important roles as adhesins during the Paracoccidioides-host interaction. For this purpose, the FaaPred software [55] was used to predict fungal adhesins and adhesin-like proteins. In our analysis, we predicted 2 proteins that might be adhesin-like proteins. Although these are preliminary results, this type of analysis demonstrates that a considerable portion of the arsenal of molecules used by Paracoccidioides while interacting with the host might still be unknown. These findings promote the need for further studies characterizing new virulence factors of this fungus.

\section{Conclusions}

Understanding the adaptive response to different growth conditions, elucidating the processes of adhesion and cell invasion, and identifying the genes that are differentially expressed during the parasite-host interaction may help elucidate the mechanisms used for survival and growth of Paracoccidioides in various human tissues. In our study, we observed that proteins related to virulence were expressed against all ECM components, which might explain the increase in fungal adhesion. The fungus-host interaction includes a complex network of signaling pathways that are interconnected with regards to protein expression in a given situation or set of conditions. One goal of this study was to identify the differentially expressed proteins of Paracoccidioides when in contact with extracellular matrix components. In this sense, the 2-DE technique was extremely useful and provided an overview of the cellular components at the particular moment of contact.

\section{Methods}

\section{Ethics statement}

The 14-3-3 and enolase rabbit preimmune serum used in this study was obtained from two previous studies, Silva et al. [26] and Donofrio et al. [31] with the approval of the Ethics Committee on Animal Experiments of the Faculty of Pharmaceutical Sciences of Araraquara UNESP, Processes Protocols 10/2011/CEUA/FCF and 08/2001/CEUA/FCF respectively. The experiments in these previous studies were performed in strict accordance with Brazilian Federal Law 11,794 that established procedures for the scientific use of animals and the state law establishing the Animal Protection Code of the State of São Paulo. All efforts were made to minimize suffering by the animals used in the current study.

\section{Strain and culture conditions}

The Paracoccidioides lutzii 01 strain (ATCC MYA-826) was used in all experiments. The yeast phase was maintained in vitro in Fava-Netto's medium [56] for 7 days at $36^{\circ} \mathrm{C}$. For the adhesion assay, the fungus was incubated under three conditions: (1) complete McVeigh-Morton (MVM) medium [57,58] containing glucose $1 \%, \mathrm{KH}_{2} \mathrm{PO}_{4}$ $11 \mathrm{mM}, \mathrm{MgSO}_{4} \cdot 7 \mathrm{H}_{2} \mathrm{O} 2 \mathrm{mM}, \mathrm{CaCl}_{2} \cdot 2 \mathrm{H}_{2} \mathrm{O} 1 \mathrm{mM},\left(\mathrm{NH}_{4}\right)$ ${ }_{2} \mathrm{SO}_{4} 15 \mathrm{mM}$, L-Asparagine $0.02 \%$, L-Cystine $0.002 \%$, vitamin supplements $1 \%$, and trace element supplement $0.1 \%$, (2) MVM without $\mathrm{Cu}$ reagent (MVM-W-Cu) and (3) MVM without Fe reagent. Moreover, bathocuproinedisulfonic acid (BCS) (Sigma-Aldrich, St. Louis, MO, USA) and bathophenanthroline disulfate (BPS) (Sigma-Aldrich, St. Louis, MO, USA) were used to chelate the $\mathrm{Cu}$ and Fe ions, respectively. The fungus maintained in Fava-Netto's medium was transferred to the three conditions described above and incubated for $3 \mathrm{~h}$ at $37^{\circ} \mathrm{C}$.

\section{Fungal adherence assays}

ECM proteins, represented by laminin, fibronectin, and types I and IV collagen (Sigma-Aldrich, St. Louis, MO, USA), were immobilized on 24-well microtiter plates at $50 \mu \mathrm{g} / \mathrm{ml}$ diluted in carbonate-bicarbonate buffer ( $\mathrm{pH}$ 9.6). The plates were incubated for $1 \mathrm{~h}$ at $25^{\circ} \mathrm{C}$, incubated overnight at $4^{\circ} \mathrm{C}$ and washed with PBS. The fungal suspensions were washed again and suspended in PBS. Suspensions $(500 \mu \mathrm{L})$ of yeast containing $10^{6}$ cells $/ \mathrm{ml}(0.5 \mathrm{OD}$ at $550 \mathrm{~nm}$ ) were transferred to microtiter plates containing ECM proteins and incubated for $2 \mathrm{~h}$ at $37^{\circ} \mathrm{C}$. The wells were washed three times with PBS, and trypsin was used to recover the cells, which were suspended in $500 \mu \mathrm{L}$ of FACSFlow $^{\circ}$ (BD, Becton Dickinson Company) and then examined by flow cytometry. All flow cytometry analyses were performed using a BD FACS Canto. The data (number of cells) were analyzed using BDFACS Diva software. The adhesion experiments were made at three independent times, in triplicate. As an experimental control, wells without ECM were inoculated with the fungal suspension and adhesion to the plate was analyzed. The adhesion values found in this control were subtracted from the adhesion values found in the tests with the different ECMs. 
Expression analysis of enolase and 14-3-3 proteins in Paracoccidioides lutzii yeast cells when interacting with ECM components after micronutrient depletion using immunogold labeling

To examine the expression of the enolase and 14-3-3 proteins of $P$. lutzii, we performed immunocytochemistry at the ultra-structural level using immunogold labeling. For each experiment, a suspension of $P$. lutzii yeast cells without $\mathrm{Cu}$ and $P$. lutzii without $\mathrm{Cu}$ in the presence of ECM components $\left(10^{8}\right.$ cells $\left./ \mathrm{ml}\right)$ were fixed $(2.5 \% \mathrm{v} / \mathrm{v}$ glutaraldehyde in $0.1 \mathrm{M}$ sodium cacodylate buffer, $\mathrm{pH} 7.2$ ) for $24 \mathrm{~h}$ at $4^{\circ} \mathrm{C}$ and sent to the electron microscopy service of the Institute of Biomedical Sciences (ICB-I) USP-SP for preparation of ultrathin sections. After fixation, the cells were rinsed several times using the same buffer, and free aldehyde groups were quenched with $50 \mathrm{mM}$ ammonium chloride for $1 \mathrm{~h}$, followed by block staining in a solution containing $2 \%(\mathrm{w} / \mathrm{v})$ uranyl acetate in $15 \%(\mathrm{v} / \mathrm{v})$ acetone for $2 \mathrm{~h}$ at $4^{\circ} \mathrm{C}$. The material was dehydrated in a series of ascending concentrations of acetone (30 to 100\% v/v) and embedded in LR Gold resin (Electron Microscopy Sciences, Washington, Pa.). The ultrathin sections were collected on nickel grids, preincubated in $10 \mathrm{mM}$ PBS containing $1.5 \%(\mathrm{w} / \mathrm{v})$ bovine serum albumin (BSA) and $0.05 \%(\mathrm{v} / \mathrm{v})$ Tween 20 (PBS-BSA-T). The sections were subsequently incubated overnight with a polyclonal antibody against the enolase and 14-3-3 proteins (diluted 1:50). After washing with PBS-BSA-T, the grids were incubated overnight with the labeled secondary antibody (rabbit IgG, Au conjugated, $10 \mathrm{~nm}$; diluted 1:10). Controls were incubated with rabbit pre-immune serum at 1:50, followed by incubation with the labeled secondary antibody. After incubation, the grids were washed with the buffer described above, followed by a wash with distilled water, and staining with $3 \%$ uranyl acetate $(\mathrm{w} / \mathrm{v})$ and $4 \%$ lead citrate $(\mathrm{w} / \mathrm{v})$. Finally, the grids were observed using a Jeol 1010 transmission electron microscope (Jeol, Tokyo, Japan). Using the software, Image Tool v. 3.00 [59], 10 different cells of each tested situation were selected and the proteins marked with gold particles were counted, providing quantitative analyses of the expression of this protein when interacting with the ECM components after $\mathrm{Cu}$ depletion.

\section{RNA isolation and CDNA synthesis}

Total RNA was extracted using the following conditions: (1) $P$. lutzii yeast cells maintained in MVM without $\mathrm{Cu}$; and (2) yeast cells cultivated in MVM without $\mathrm{Cu}$, incubated for $3 \mathrm{~h}$ at $37^{\circ} \mathrm{C}$ followed by the addition of the different ECM components (laminin, fibronectin, and types I and IV collagen) at $50 \mu \mathrm{g} / \mathrm{ml}$, and incubated for an additional $2 \mathrm{~h}$ at $37^{\circ} \mathrm{C}$. These preps were used for the Real Time PCR assays.

Total RNA was extracted from all experimental conditions using Trizol reagent (Invitrogen Life Technologies, Carlsbad, CA). First-strand cDNA synthesis was performed using reverse transcriptase (RevertAid ${ }^{\mathrm{mm}} \mathrm{H}$ Minus Reverse
Transcriptase, Fermentas Life Sciences, Canada) and $1 \mu \mathrm{g}$ of total RNA. First-strand cDNA was used as a template to synthesize the second-strand of cDNA using the SMART PCR cDNA synthesis kit (Clontech Laboratories, Palo Alto, CA, USA).

\section{Proteomic analysis of Paracoccidioides lutzii protein expression during $\mathrm{Cu}$ deprivation in the presence of different ECM components}

The total protein extracts of $P$. lutzii were obtained in the yeast phase under different conditions, as shown in Table 3, to isolate and characterize the proteins differentially expressed in the different conditions.

Cells from P. lutzii in the yeast phase submitted to the different conditions (Table 3) were centrifuged (5000 $g$ for 10 $\mathrm{min}$ ) and washed 3-5 times with cold water to remove the culture medium. Then, $10 \mathrm{mM}$ Tris $-\mathrm{HCl}$ and protease inhibitors $(1 \mathrm{mM}$ pepstatin, $1 \mathrm{mM}$ leupeptin, $1 \mathrm{mM}$ aprotin, 1 $\mathrm{mM}$ antipain, $1 \mathrm{mM}$ chymostatin and $1 \mathrm{mM}$ PMSF) were added to the pellet, which was subsequently homogenized with liquid nitrogen, macerated with glass beads and vortexed for $30 \mathrm{~min}$. This preparation was then centrifuged for $45 \mathrm{~min}$ at $13000 \mathrm{~g}$, and the supernatant collected. The protein concentration of the extracts was quantified using the Bradford Assay [60] (Bio-Rad Laboratories, California, USA). The samples were then analyzed by SDS-PAGE. The protein components of the extracts were subjected to isoelectric focusing using EttanIPGphor 3 (GE Healthcare, Buckinghamshire, UK). The second dimension, performed to separate proteins according to molecular weight, was conducted in a $12.5 \%$ polyacrylamide gel according to Laemmli et al. [61]. The gels were stained with Coomassie Brilliant Blue G-350 [62]. The data analysis was performed using Image Master 2D Platinum software (GE Healthcare, Buckinghamshire, UK) to compare the protein profile of the P. lutzii depleted of $\mathrm{Cu}$ before and after the fungus came into contact with the different ECM components. The 2D Platinum software analyzes the volumes of the spots and determines how much the expression of the selected spots were increased or decreased when compared with the control (P. lutzii without $\mathrm{Cu}$ ) and our tests (P. lutzii without $\mathrm{Cu}$ in contact with the different ECM components)".

Table 3 Conditions of $\boldsymbol{P}$. lutzii tested by proteomic assays

\begin{tabular}{ll}
\hline & Condition \\
\hline 0 & P. lutzii maintained in MVM without Cu \\
2 & P. lutzii maintained in MVM without Cu + laminin \\
3 & P. lutzii maintained in MVM without $\mathrm{Cu}+$ fibronectin \\
4 & P. lutzii maintained in MVM without $\mathrm{Cu}+$ type I collagen \\
\hline
\end{tabular}




\section{Protein identification by mass spectrometry (MS)}

Protein spots were excised from 2-DE gels, cut, distained, reduced, alkylated and subjected to tryptic digestion using $10 \mathrm{ng} / \mathrm{ml}$ of Trypsin Gold (Promega Corporation, Wisconsin, USA), according to Celedon et al. [63]. After digestion, the peptides were extracted twice with [50 $\mu \mathrm{L}$ of $60 \%(\mathrm{v} / \mathrm{v})$ methanol, $1 \%$ $(\mathrm{v} / \mathrm{v})$ formic acid (FA)], twice with [50 $\mu \mathrm{L}$ of $50 \%(\mathrm{v} /$ v) acetonitrile $(\mathrm{ACN})$ and MS-grade-water, 1\% (v/v) FA] and once with $50 \mu \mathrm{L}$ of ACN (100\%). All supernatants were combined and vacuum dried. Peptides were then suspended in $13 \mu \mathrm{L}$ of $0.1 \%(\mathrm{v} / \mathrm{v})$ FA for MS analysis. Peptide masses were measured using a nanoelectrospray ionization quadrupole time-of-flight hybrid mass spectrometer (Q-TOF Ultima; Waters) coupled to a nano-HPLC (Cap-LC, Waters), as described by Fiorani Celedon et al. [63]. The resulting spectra were processed using ProteinLynx v.4.0 software (Waters) and MASCOT MS/MS Ion Search (www.matrixscience.com). The sequences were compared with those in the NCBI and SwissProt databanks.

\section{Real-time PCR}

Real-time PCR analysis was used for three different purposes in this study:

1) to evaluate the adhesin gene expression during contact between $P$. lutzii and the different ECM in $\mathrm{Cu}$-depleted conditions. For this, we evaluated the gene expression of 6 known adhesins: enolase (ENO), Glyceraldehyde-3-phosphate dehydrogenase (GAPDH), GP43, malate synthase (MLT), triosephosphate isomerase (TPI), and 14-3-3;

2) to confirm the differential expression of the proteins found in the proteomics assay. To do so, we compared the cDNA of $P$. lutzii grown in $\mathrm{Cu}$ depleted conditions with the cDNA of $P$. lutzii grown in $\mathrm{Cu}$-depleted conditions but in contact with one of the four ECM components. We used 12 different primers: cell surface protein (CS protein), cytokine-inducing glycoprotein (CIGI), ENO, glucose-6-phosphate dehydrogenase (G6PD), glutamine synthetase (GSA), RDS1 protein (RDS1), 14-3-3, aldolase (ALD), GAPDH, serine/threonineprotein kinase CBK1 (CBK1), siderophore Fe transporter (ENB1), and vesicle-mediated transport-related protein (VES);

3) to evaluate the expression of the adhesin-like proteins identified in the proteomics assay. We used 2 primers for this purpose: emb|CBX92058.1| and gb| EFQ27774.1|. The SIGLA used to name the primers corresponded to the accession number of the studied gene.
The reaction mixtures contained $2 \mu \mathrm{L}$ of cDNA (40 ng), $12.5 \mu \mathrm{L}$ of Maxima ${ }^{\bullet}$ SYBR Green/ROX qPCR Master Mix (2x) (Thermo Fisher Scientific, Massachusetts, USA), and $0.5 \mu \mathrm{M}$ of forward and reverse primers. The volume was brought to $25 \mu \mathrm{L}$ with nuclease-free water. The reaction program was as follows: $50^{\circ} \mathrm{C}$ for $2 \mathrm{~min}, 95^{\circ} \mathrm{C}$ for $10 \mathrm{~min}$, 40 cycles of $95^{\circ} \mathrm{C}$ for $15 \mathrm{~s}$, and a period of annealing and synthesis at $60^{\circ} \mathrm{C}$ for $1 \mathrm{~min}$. Following the PCR, a meltingcurve analysis was performed, which confirmed that the signal corresponded to a single PCR product. The reactions were performed in an Applied Biosystems 7500 cycler. The data were analyzed using the $2^{-\triangle \Delta C T}$ method. The cycle threshold values for the duplicate PCRs for each RNA sample were averaged, and then the $2^{-\Delta \Delta C T}$ values were calculated. The constitutive gene encoding the $60 \mathrm{~S}$ ribosomal L34 was used as the endogenous control. A negative-control sample containing all reagents except $P$. lutzii cDNA was used. After 40 rounds of amplification, no PCR products were detected in this reaction. These experimental results represent numbers of three independent experiments in triplicate.

All of the primer sequences used in the real-time PCR are listed in Additional file 1: Table S1.

\section{In silico analysis of putative proteins identified in 2D-E analysis for adhesin-like protein predictions}

To predict adhesin-like proteins, we used the software, FaaPred (Fungal Adhesins and Adhesin-like proteins predictions), developed by Ramana and Gupta [55]; this software uses an SVM-based method (Support Vector Machine) to identify fungal adhesins available on-line (http://bioinfo.icgeb.res.in/faap/). This software searches for N-terminal carbohydrates or peptide-binding domains, central Ser-and Thr-rich glycosylated domains and Cterminal regions that mediate covalent cross-linking to the fungal cell wall through modified glycosyl phosphatidyl inositol (GPI).

\section{Statistical analyses}

All statistical analyses were performed using one-way ANOVA with Tukey's coefficient. The results of the statistical analyses were considered significant when the $p$ value was $<0.05$. These analyses and graphs were made using Prism 5 (GraphPad Software Inc.).

\section{Additional file}

Additional file 1: Table S1. Primers used for the real-time PCR assays.

\section{Competing interests}

The authors declare that they have no competing interests.

\section{Authors' contributions}

HCO and MJSMG conceived and designed the experiments. HCO, JFS, MTM, CMM, RPS, RAMS and MTVL performed the experiments. HCO, JFS, MTM, 
CMM, RPS, MTVL, CAL, AMFA and MJSMG analysed the data. HCO, JFS, CMM, CAL, MJSMG drafted the manuscript. All authors read and approved the final manuscript.

\section{Acknowledgments}

We are very grateful to Gaspar Ferreira de Lima and Edson Rocha de Oliveira for their technical assistance with electron microscopy. This investigation was financially supported by the Brazilian Organizations: FAPESP (Processes Numbers 2008/56476-5, 2009/52046-9 and 2011/18038-9), National Council for Scientific and Technological Development (Process number 473119/2010-2), PADCFCF-São Paulo State University.

\section{Author details}

1Departamento de Análises Clínicas, Faculdade de Ciências Farmacêuticas, UNESP - Univ Estadual Paulista, Laboratório de Micologia Clinica, Rodovia Araraquara-Jaú, Km 1, Araraquara, SP, Brazil. ²Departamento de Genética, Escola Superior de Agricultura "Luiz de Queiroz, Universidade de São Paulo, Laboratório Multiusuários Centralizado de Genômica Funcional Aplicada à Agropecuária e Agroenergia, Piracicaba, São Paulo, Brazil.

Received: 7 July 2014 Accepted: 19 November 2014

Published online: 13 December 2014

\section{References}

1. Matute DR, McEwen JG, Puccia R, Montes BA, San-Blas G, Bagagli E, Rauscher JT, Restrepo A, Morais F, Niño-Vega G, Taylor JW: Cryptic speciation and recombination in the fungus Paracoccidioides brasiliensis as revealed by gene genealogies. Mol Biol Evol 2006, 23(1):65-73.

2. Matute DR, Sepulveda VE, Quesada LM, Goldman GH, Taylor JW, Restrepo A, McEwen JG: Microsatellite analysis of three phylogenetic species of Paracoccidioides brasiliensis. J Clin Microbiol 2006, 44(6):2153-2157.

3. Carrero LL, Niño-Vega G, Teixeira MM, Carvalho MJ, Soares CM, Pereira M, Jesuino RS, McEwen JG, Mendoza L, Taylor JW, Felipe MS, San-Blas G: New Paracoccidioides brasiliensis isolate reveals unexpected genomic variability in this human pathogen. Fungal Genet Biol 2008, 45(5):605-612

4. Teixeira MM, Theodoro RC, de Carvalho MJ, Fernandes L, Paes HC, Hahn RC, Mendoza L, Bagagli E, San-Blas G, Felipe MS: Phylogenetic analysis reveals a high level of speciation in the Paracoccidioides genus. Mol Phylogenet Evol 2009, 52(2):273-283.

5. Franco M: Host-parasite relationships in paracoccidioidomycosis. J Med Vet Mycol 1987, 25(1):5-18

6. Mendes-Giannini MJ, Taylor ML, Bouchara JB, Burger E, Calich VL, Escalante ED, Hanna SA, Lenzi HL, Machado MP, Miyaji M, Monteiro Da Silva JL, Mota EM, Restrepo A, Restrepo S, Tronchin G, Vincenzi LR, Xidieh CF, Zenteno E: Pathogenesis II: fungal responses to host responses: interaction of host cells with fungi. Med Mycol 2000, 38(Suppl 1):113-123.

7. Mendes-Giannini MJ, Monteiro da Silva JL, de Fátima da Silva J, Donofrio FC, Miranda ET, Andreotti PF, Soares CP: Interactions of Paracoccidioides brasiliensis with host cells: recent advances. Mycopathologia 2008, 165(4-5):237-248.

8. Sampermans S, Mortier J, Soares EV: Flocculation onset in Saccharomyces cerevisiae: the role of nutrients. J Appl Microbiol 2005, 98(2):525-531.

9. Kim BE, Nevitt T, Thiele DJ: Mechanisms for copper acquisition, distribution and regulation. Nat Chem Biol 2008, 4(3):176-185.

10. Rutherford JC, Bird AJ: Metal-responsive transcription factors that regulate iron, Zn, and copper homeostasis in eukaryotic cells. Eukaryot Cell 2004, 3(1):1-13.

11. Silva MG, Schrank A, Bailão EF, Bailão AM, Borges CL, Staats CC, Parente JA, Pereira M, Salem-Izacc SM, Mendes-Giannini MJ, Oliveira RM, Silva LK, Nosanchuk JD, Vainstein MH, de Almeida Soares CM: The homeostasis of iron, copper, and $\mathrm{Zn}$ in paracoccidioides brasiliensis, cryptococcus neoformans var. Grubii, and cryptococcus gattii: a comparative analysis. Front Microbiol 2011, 2:49.

12. Lan CY, Rodarte G, Murillo LA, Jones T, Davis RW, Dungan J, Newport G, Agabian N: Regulatory networks affected by iron availability in Candida albicans. Mol Microbiol 2004, 53(5):1451-1469.

13. Ramanan N, Wang Y: A high-affinity iron permease essential for Candida albicans virulence. Science 2000, 288(5468):1062-1064

14. Gancz H, Censini S, Merrell DS: Iron and pH homeostasis intersect at the level of Fur regulation in the gastric pathogen Helicobacter pylori. Infect Immun 2006, 74(1):602-614.
15. Waterman SR, Hacham M, Hu G, Zhu X, Park YD, Shin S, Panepinto J, Valyi-Nagy T, Beam C, Husain S, Singh N, Williamson PR: Role of a CUF1/ CTR4 copper regulatory axis in the virulence of Cryptococcus neoformans. J Clin Invest 2007, 117(3):794-802.

16. Dias-Melicio LA, Calvi SA, Peraçoli MT, Soares AM: Inhibitory effect of deferoxamine on Paracoccidioides brasiliensis survival in human monocytes: reversal by holotransferrin not by apotransferrin. Rev Inst Med Trop Sao Paulo 2005, 47(5):263-266.

17. Parente $A F$, Bailão $A M$, Borges $C L$, Parente $J A$, Magalhães $A D$, Ricart $C A$, Soares CM: Proteomic analysis reveals that iron availability alters the metabolic status of the pathogenic fungus Paracoccidioides brasiliensis. PLOS ONE 2011, 6(7):e22810.

18. da Fonseca CA, Jesuino RS, Felipe MS, Cunha DA, Brito WA, Soares CM: Two-dimensional electrophoresis and characterization of antigens from Paracoccidioides brasiliensis. Microbes Infect 2001, 3(7):535-542.

19. Borges CL, Bailão AM, Báo SN, Pereira M, Parente JA, de Almeida Soares CM: Genes potentially relevant in the parasitic phase of the fungal pathogen Paracoccidioides brasiliensis. Mycopathologia 2011, 171(1):1-9.

20. Nogueira SV, Fonseca FL, Rodrigues ML, Mundodi V, Abi-Chacra EA, Winters MS, Alderete JF, de Almeida Soares CM: Paracoccidioides brasiliensis enolase is a surface protein that binds plasminogen and mediates interaction of yeast forms with host cells. Infect Immun 2010, 78(9):4040-4050.

21. Rezende $T C$, Borges $C L$, Magalhães $A D$, de Sousa MV, Ricart CA, Bailão $A M$, Soares CM: A quantitative view of the morphological phases of Paracoccidioides brasiliensis using proteomics. J Proteomics 2011, 75(2):572-587.

22. Vallejo MC, Nakayasu ES, Longo LV, Ganiko L, Lopes FG, Matsuo AL, Almeida IC, Puccia R: Lipidomic analysis of extracellular vesicles from the pathogenic phase of Paracoccidioides brasiliensis. PLOS ONE 2012, 7(6):e39463.

23. Vallejo MC, Nakayasu ES, Matsuo AL, Sobreira TJ, Longo LV, Ganiko L, Almeida IC, Puccia R: Vesicle and vesicle-free extracellular proteome of Paracoccidioides brasiliensis: comparative analysis with other pathogenic fungi. J Proteome Res 2012, 11(3):1676-1685.

24. Weber SS, Parente AF, Borges CL, Parente JA, Bailão AM, de Almeida Soares CM: Analysis of the secretomes of Paracoccidioides mycelia and yeast cells. PLOS ONE 2012, 7(12):e52470.

25. de Arruda Grossklaus D, Bailão AM, Vieira Rezende TC, Borges CL, de Oliveira MA, Parente JA, de Almeida Soares CM: Response to oxidative stress in Paracoccidioides yeast cells as determined by proteomic analysis. Microbes Infect 2013, 15(5):347-364.

26. da Silva JF, de Oliveira HC, Marcos CM, da Silva RA, da Costa TA, Calich VL, Almeida AM, Mendes-Giannini MJ: Paracoccidoides brasiliensis $30 \mathrm{kDa}$ Adhesin: identification as a 14-3-3 protein, cloning and subcellular localization in infection models. PLOS ONE 2013, 8(4):e62533.

27. Marcos CM, de Fátima da Silva J, de Oliveira HC, da Silva RA M, Mendes-Giannini MJ, Fusco-Almeida AM: Surface-expressed enolase contributes to the adhesion of Paracoccidioides brasiliensis to host cells. FEMS Yeast Res 2012, 12(5):557-570.

28. Eide DJ: The molecular biology of metal ion transport in Saccharomyces cerevisiae. Annu Rev Nutr 1998, 18:441-469.

29. De Freitas J, Wintz H, Kim JH, Poynton H, Fox T, Vulpe C: Yeast, a model organism for iron and copper metabolism studies. Biometals 2003, 16(1):185-197.

30. Donofrio FC, Calil AC, Miranda ET, Almeida AM, Benard G, Soares CP, Veloso SN, Soares CM, Mendes Giannini MJ: Enolase from Paracoccidioides brasiliensis: isolation and identification as a fibronectin-binding protein. J Med Microbiol 2009, 58(Pt 6):706-713.

31. Barbosa MS, Báo SN, Andreotti PF, de Faria FP, Felipe MS, dos Santos FL, Mendes-Giannini MJ, Soares CM: Glyceraldehyde-3-phosphate dehydrogenase of Paracoccidioides brasiliensis is a cell surface protein involved in fungal adhesion to extracellular matrix proteins and interaction with cells. Infect Immun 2006, 74(1):382-389.

32. Carneiro LC, de Faria FP, Felipe MS, Pereira M, de Almeida Soares CM: Paracoccidioides brasiliensis presents two different cDNAs encoding homologues of the fructose 1,6-biphosphate aldolase: protein isolation, cloning of the cDNAs and genes, structural, phylogenetic, and expression analysis. Fungal Genet Biol 2005, 42(1):51-60.

33. Pancholi V: Multifunctional alpha-enolase: its role in diseases. Cell Mol Life Sci 2001, 58(7):902-920.

34. Carneiro CR, Postol E, Nomizo R, Reis LF, Brentani RR: Identification of enolase as a laminin-binding protein on the surface of Staphylococcus aureus. Microbes Infect 2004, 6(6):604-608 
35. Mundodi V, Kucknoor AS, Alderete JF: Immunogenic and plasminogenbinding surface-associated alpha-enolase of Trichomonas vaginalis. Infect Immun 2008, 76(2):523-531.

36. Bergmann S, Rohde M, Chhatwal GS, Hammerschmidt S: Alpha-Enolase of Streptococcus pneumoniae is a plasmin(ogen)-binding protein displayed on the bacterial cell surface. Mol Microbiol 2001, 40(6):1273-1287.

37. Vanegas G, Quiñones W, Carrasco-López C, Concepción JL, Albericio F, Avilán L: Enolase as a plasminogen binding protein in Leishmania mexicana. Parasitol Res 2007, 101(6):1511-1516.

38. Bernal D, de la Rubia JE, Carrasco-Abad AM, Toledo R, Mas-Coma S, Marcilla $A$ : Identification of enolase as a plasminogen-binding protein in excretory-secretory products of Fasciola hepatica. FEBS Lett 2004, 563(1-3):203-206.

39. Coleman JL, Gebbia JA, Piesman J, Degen JL, Bugge TH, Benach JL: Plasminogen is required for efficient dissemination of $B$. burgdorferi in ticks and for enhancement of spirochetemia in mice. Cell 1997, 89(7):1111-1119.

40. Lähteenmäki K, Edelman S, Korhonen TK: Bacterial metastasis: the host plasminogen system in bacterial invasion. Trends Microbio/ 2005, 13(2):79-85.

41. van Heusden GP: 14-3-3 Proteins: insights from genome-wide studies in yeast. Genomics 2009, 94(5):287-293.

42. DeLille JM, Sehnke PC, Ferl RJ: The arabidopsis 14-3-3 family of signaling regulators. Plant Physiol 2001, 126(1):35-38.

43. Darling DL, Yingling J, Wynshaw-Boris A: Role of 14-3-3 proteins in eukaryotic signaling and development. Curr Top Dev Biol 2005, 68:281-315.

44. Obsil T, Obsilova V: Structural basis of 14-3-3 protein functions. Semin Cell Dev Biol 2011, 22(7):663-672.

45. Mendes-Giannini MJ, Andreotti PF, Vincenzi LR, da Silva JL, Lenzi HL, Benard G, Zancopé-Oliveira R, de Matos Guedes HL, Soares CP: Binding of extracellular matrix proteins to Paracoccidioides brasiliensis. Microbes Infect 2006, 8(6):1550-1559.

46. Andreotti PF, Monteiro da Silva JL, Bailão AM, Soares CM, Benard G, Soares $\mathrm{CP}$, Mendes-Giannini MJ: Isolation and partial characterization of a $30 \mathrm{kDa}$ adhesin from Paracoccidioides brasiliensis. Microbes Infect 2005, 7(5-6):875-881.

47. McCarthy JS, Wieseman M, Tropea J, Kaslow D, Abraham D, Lustigman S, Tuan R, Guderian RH, Nutman TB: Onchocerca volvulus glycolytic enzyme fructose-1,6-bisphosphate aldolase as a target for a protective immune response in humans. Infect Immun 2002, 70(2):851-858.

48. Pitarch A, Sánchez M, Nombela C, Gil C: Sequential fractionation and twodimensional gel analysis unravels the complexity of the dimorphic fungus Candida albicans cell wall proteome. Mol Cell Proteomics 2002, 1(12):967-982.

49. Froissard M, Belgareh-Touzé N, Dias M, Buisson N, Camadro JM, Haguenauer-Tsapis R, Lesuisse E: Trafficking of siderophore transporters in Saccharomyces cerevisiae and intracellular fate of ferrioxamine B conjugates. Traffic 2007, 8(11):1601-1616.

50. Racki WJ, Bécam AM, Nasr F, Herbert CJ: Cbk1p, a protein similar to the human myotonic dystrophy kinase, is essential for normal morphogenesis in Saccharomyces cerevisiae. EMBO J 2000, 19(17):4524-4532.

51. Kuravi VK, Kurischko C, Puri M, Luca FC: Cbk1 kinase and Bck2 control MAP kinase activation and inactivation during heat shock. Mol Biol Cell 2011, 22(24):4892-4907.

52. Colman-Lerner A, Chin TE, Brent R: Yeast Cbk1 and Mob2 activate daughter-specific genetic programs to induce asymmetric cell fates. Cell 2001, 107(6):739-750.

53. Gutiérrez-Escribano P, Zeidler U, Suárez MB, Bachellier-Bassi S, ClementeBlanco A, Bonhomme J, Vázquez de Aldana CR, d'Enfert C, Correa-Bordes J: The NDR/LATS kinase Cbk1 controls the activity of the transcriptional regulator Bcr1 during biofilm formation in Candida albicans. PLOS Pathog 2012, 8(5):e1002683.

54. Vallejo MC, Matsuo AL, Ganiko L, Medeiros LC, Miranda K, Silva LS, Freymüller-Haapalainen E, Sinigaglia-Coimbra R, Almeida IC, Puccia R: The pathogenic fungus Paracoccidioides brasiliensis exports extracellular vesicles containing highly immunogenic a-Galactosyl epitopes. Eukaryot Cell 2011, 10(3):343-351.

55. Ramana J, Gupta D: FaaPred: a SVM-based prediction method for fungal adhesins and adhesin-like proteins. PLoS ONE 2010, 5(3):e9695.
56. FAVA NETTO C: Contribuição para o estudo imunológico da blastomicose de Lutz (Blastomicosesulamericana). In., vol. 21. São Paulo: Rev. Inst. A. Lutz; 1961:99-194.

57. McVeigh I, Morton K: Nutritional studies of Histoplasma capsulatum. Mycopathol Mycol Appl 1965, 25(3):294-308.

58. Restrepo A, Jiménez BE: Growth of Paracoccidioides brasiliensis yeast phase in a chemically defined culture medium. J Clin Microbiol 1980, 12(2):279-281.

59. Wilcox D, Dove B, McDavid D, Greer D: UTHSCSA Image Tool 3.0. San Antonio, TX: UTHSCSA; 2002.

60. Bradford MM: A rapid and sensitive method for the quantitation of microgram quantities of protein utilizing the principle of protein-dye binding. Anal Biochem 1976, 7(72):248-254.

61. Laemmli UK: Cleavage of structural proteins during the assembly of the head of bacteriophage T4. Nature 1970, 227(5259):680-685.

62. Neuhoff $V$, Arold N, Taube D, Ehrhardt W: Improved staining of proteins in polyacrylamide gels including isoelectric focusing gels with clear background at nanogram sensitivity using Coomassie Brilliant Blue G250 and R-250. Electrophoresis 1988, 9(6):255-262.

63. Fiorani Celedon PA, de Andrade A, Meireles KG, Gallo de Carvalho MC, Caldas DG, Moon DH, Carneiro RT, Franceschini LM, Oda S, Labate CA: Proteomic analysis of the cambial region in juvenile Eucalyptus grandis at three ages. Proteomics 2007, 7(13):2258-2274.

\section{Submit your next manuscript to BioMed Central and take full advantage of:}

- Convenient online submission

- Thorough peer review

- No space constraints or color figure charges

- Immediate publication on acceptance

- Inclusion in PubMed, CAS, Scopus and Google Scholar

- Research which is freely available for redistribution

Submit your manuscript at www.biomedcentral.com/submit
C) BioMed Central 